\title{
Tissue Culture of Cucumis Melo
}

\author{
Ismail Bezirganoglu* \\ Department of Molecular Biology and Genetic Erzurum, Erzurum Technical University, Turkey
}

Submission: March 25, 2017; Published: April 26, 2017

"Corresponding author: Ismail Bezirganoglu, Department of Molecular Biology and Genetic Erzurum, Erzurum Technical University, Turkey, Tel: 905072798773; Email: ismail.bezirganoglu@erzurum.edu.tr

\section{Mini Review}

The development of tissue culture in specific artificial medium is aimed to regenerate pieces of leaves, cotyledons, hypocotyls, ovary, protoplast, petiole, anthers, stem or root. Regeneration of plants in tissue culture has been achieved for various plant species, including Cucumis melo and others members of the family Cucurbitaceae [1]. A broad range of cultivars, using a variety of explant sources, culture media, concentrations of plant growth regulators, as well as controlled environmental conditions has been accomplished for tissue culture of $C$. melo. Research in tissue culture of $C$. melo has covered a wide range of techniques including micro propagation, of organ culture regeneration from callus cultures via organogenesis or embryogenesis, anther pollen culture and cell suspension culture. The genetic improvement of $C$. melo could be achieved through tissue culture since the genetic variability of this crop is limited by sexual incompatibility with other species in Cucurbitaceae. In addition, tissue culture of cucumis could be useful to achieve variability via somaclonal variation. For instance, tissue culture may also facilitate selection of certain Cucum is and other cucurbits for desirable cell or tissue variants, such as those showing higher resistance to a fungus or a fungal toxin, and tolerance to higher concentration of salts.

Tissue culture in genetic transformation can be used as an alternative for introducing variability by incorporating foreign genes into the crops. However, an efficient system for plant regeneration is essential for in vitro techniques to be useful in achieving these goals. Most researches recently focused on improving regeneration of plantlets from callus and cell cultures, in addition to pursuing an efficient transfer of foreign genes into C. melo. Most studies prefer to use aseptically grown seedlings as the explant source because surface sterilization problems associated with explants taken directly from field or green-house grown plants can be avoided. These aseptical tissues include cotyledons, true leaves, hypocotyl segments, petiols, internode segments, shoots tips, modal cuttings, immature zygotic embryos and anthers. A few studies use tissue culture for micro propagation of $C$. melo by somatic embryogenesis. Akasaka et al. [2], used cotyledon and hypocotyl explants to achieve shoot. For optimal shoot multiplication, low concentrations of auxin and cytokinin with a combination of $0.1 \mathrm{mg} / \mathrm{l}$ each of benzyl aminopurine (BA) and $2 \mathrm{mg} / \mathrm{l}$ of 2,4-D are required. Calli and embryos were obtained in embryo induction selection medium containing 25mg/l kanamycin and $375 \mathrm{mg} / \mathrm{l}$ augmentin 9 weeks after bacterial inoculation. For a similar purpose, Marta \& Andres [3], cultured cotyledon explants of seven "criollo" melon (Cucumis melo L) genotypes which were evaluated with regard to their morphogenic responses to combinations of N6benzylaminopurine (BAP) $(0.1,0.5$ and $1.0 \mathrm{mg} / 1)$ with indole-3acetic acid (IAA) $(0,0.05$ and $0.5 \mathrm{mg} / 1)$. Regardless of BAP and IAA concentration in the shoot induction medium, the highest shoot formation percentages were obtained using EM-1, followed by OSO-1, PQRG-3, OSO-2, PQRG-2, PQRG-1 and OSO-3. On the other hand, independently of the genotype, the shoot induction medium supplemented with $0.5 \mathrm{mg} / 1 \mathrm{BAP}$ and $0.05 \mathrm{mg} / 1 \mathrm{IAA}$ or $1 \mathrm{mg} / 1 \mathrm{BAP}$ alone resulted in the highest average of shoots. Culture of cotyledons of the genotypes evaluated on induction medium supplemented with different BAP and IAA resulted in a different response. The ability to regenerate whole plants from cultured cells, protoplasts or undifferentiated tissue is an important pre-requisite for the application of plant tissue culture to genetic improvement. Plantlet regeneration from somatic tissues of C. melo, as well of other members of cucurbitaceae, may be accomplished either through somatic embryogenesis or organogenesis. In somatic embryogenesis, somatic cells of explants are used to produce embryos (direct somatic embryogenesis) or callus from which embryos are developed (indirect somatic organogenesis). In somatic embryogenesis, somatic tissues of explants are used directly to produce shoots, roots or other organs (direct somatic organogenesis), or calli developed first from explants are regenerated into these organs (indirect somatic organogenesis). Various factors, including genotype, explants type, environmental conditions of culture and the use of plant growth regulators influence the ability of $C$. 
melo tissue culture to undergo both somatic embryogenesis and organogenesis. In vitro morphogenesis of $C$. melo var. flexuosus (L.), naudin was studied by direct organogenesis. Induction of adventitious buds was obtained from distal and proximal parts of the cotyledon incubated on Murashige \& Skoog [4], medium containing different concentrations of 6-benzyladenine (BA) $(0.0,0.5,1.0$, and $2.0 \mathrm{mg} / \mathrm{L})$ and indole-3-acetic acid (IAA) $(0.0,0.1$, and $0.5 \mathrm{mg} / \mathrm{L})$. The best organogenesis was obtained from the proximal part of the cotyledon on medium containing $0.5 \mathrm{mg} / \mathrm{L} \mathrm{BA}$ and $0.5 \mathrm{mg} / \mathrm{L}$ IAA $(88 \%)$.

\section{References}

1. Wehner TC, Cade RM, Locy RD (1990) Cell, tissue and organ culture techniques for genetic improvement of cucurbits. In: Robinson RW (Ed.), Proc Intl Conf Biol Chem Cucurbitaceae, pp. 367-381.

2. Akasaka-Kennedy Y, Tomita K, Ezura H (2004) Efficient plant regeneration and Agrobacterium-mediated transformation via somatic embryogenesis in melon (Cucumis melo L.). Plant Sci 166: 763-769.

3. Marta VM, Andrés M, Gatica A (2009) Effect of BAP and IAA on shoot regeneration in explants of costarican melon genotypes. Agronomía Costarricense 33: 125-131.

4. Murashige T, Skoog F (1962) A revised medium for rapid growth and bioassays with tobacco cultures. Physiol Plant 15: 473-497.

\section{Your next submission with Juniper Publishers will reach you the below assets}

- Quality Editorial service

- Swift Peer Review

- Reprints availability

- E-prints Service

- Manuscript Podcast for convenient understanding

- Global attainment for your research

- Manuscript accessibility in different formats ( Pdf, E-pub, Full Text, Audio)

- Unceasing customer service

Track the below URL for one-step submission https://juniperpublishers.com/online-submission.php 